\title{
FDI \& economic growth in selected Country groups for (1989-2018)
}

\author{
Khalil Ghazi Hassan
}

\author{
Department of Economic, College of Administration and Economics, University of Duhok. Kurdistan Region, Iraq
}

\begin{abstract}
Theoretically, it is heavily believed that FDI is as a source of development, modernization, income, and employment growth and that FDI boosts the productivity of host countries and promotes economic growth. This paper examines, within a growth theory framework, the role which foreign direct investment (FDI) plays in the growth process in the context of different income group countries characterized by their per capita income. The paper tests (using time series data relating High, Middle- and Low-income countries) the hypothesis adopted is that FDI, enhance economic growth. The estimated indicators show evidence of rejecting Null hypothesis in the case of High- and Middle-income group countries but, vice versa the Null hypothesis is accepted for Low-income group countries.
\end{abstract}

Keywords: Foreign direct investment; economic growth; unit root; cointegration

\section{Introduction}

Several countries have been heavily concerned with Foreign Direct Investment (FDI) as a source of development, modernization, income, and employment growth. The countries have liberalized their regulations and designed and implemented many policies that would attract these investments within national plans aimed at adapting local policies to maximize the benefits of direct and indirect advantages that have established their theoretical and experimental framework. At the core level of development, FDI generates savings related to technology transfer, human capital formation and contributes to international trade integration, helping to provide a more competitive environment in business and enterprise development. Economic growth (EG), which in turn is the only outlet for the removal of poverty in developing countries (OECD, 2002).

Several studies have also shown that there is a clear disparity in the rates of growth achieved between the countries hosting FDI and on the other hand, there were doubts about the ability of some host countries to have these benefits. This is why many economists have sought to find out the nature of the relationship between economic growth and its short- and long-run stability. The question that needs to be answered is whether FDI affects economic growth in all international country groups? And, is this effect equivalent to all the individual income levels achieved? Perhaps the answer to this question is the main objective this study. Accordingly, this study will be an attempt to test the hypothesis of a positive and significant relationship between FDI and economic growth, and analyse the estimated parameters relating to the relationships between (EG), i.e. annual growth rate of real Gross Domestic product(GDP) and, (FDI) i.e. the net inflows of FDI as a percentage of GDP, of a variety of countries according to their per capita income levels, as classified by world bank criteria. While these include different levels and structures of GDP and other economic characteristics associated with abundant resources, education levels, economic policies, and various development indicators, each group has its relatively close economic characteristics. This is supposed to 
provide an opportunity to compare the results. For this purpose, statistical and standard tests will be used to estimate the relationships between the variables to be introduced to econometrics models. The paper proceeds as follows. Section II \& III briefly presents a Theoretical framework \& literature review of FDI and real GDP. Section IV describes the data and deals with the methodological issues used in the empirical analysis, while in Section V the empirical evidence is presented. Finally, in Section VI, the conclusions of the analysis are summarized.

\section{Theoretical Framework}

Economic theory has identified various effects of FDI on the economic growth of its host countries, including that FDI is a formula for the import of capital, so the domestic investment can become higher than domestic accumulation and this will increase the rate of economic growth (Lasbrey A.,2018). In recent years, however, doubts have been raised as to whether the importation of foreign accumulation would actually increase the rate of investment or only become a substitute for domestic savings leading to higher levels of current spending and higher living standards in developing countries? Such a trend has been observed in many developing countries and more clearly in the least developed countries. To answer these questions, most empirical works (Barro 1991, Grier and Tullock 1989, Kormendi, 1985) focus on the interpretation of the strongest variables to influence the size of economic growth (Ciccone A. 2008, Kormendi,1985and Kevin B. Grier \& Tullock, 1989). Ghazali argued two potential links between FDI and domestic investment; Firstly, FDI affects the profitability of domestic investment and, secondly, FDI is likely to alter the ownership structure of total investment in the host country and provides additional funding for the domestic investment (Ghazali A., 2010).

Classical economists did not take into consideration the issue of technological development, even though they were the first to take care of the determinants of economic growth. For classical, growth always depends on where the declining yield of the economy begins. Neoclassical economists, the proposed growth model by Solow in 1956, provide an explanation for growth from the production function of Cobb-Douglas: $\mathrm{Y}=\mathrm{A}$. F $(\mathrm{K}, \mathrm{L})$ (Solow, 1956).

Where $\mathrm{Y}$ represents the output, a technical development, K capital, L Labour and, production has been achieved with the help of the production of technological development A, is represented in this model. Thus, an increase in the factors of production always leads to weaker growth. Thus, it is the technological development and its limit that is capable of removing the economy from the state of stillness and generating longrun growth (Bezić H.,2014).

Barro believes that if the current output of a country is below the level of the stable state, the catch-up process occurs mainly through technology transfer, and the main factors that helped to generate growth are high levels of education, health and low birth rates (Barro R.,1991).

As FDI is a channel for the transfer of technology between countries, the high level of technological progress in the hosting sector can be transferred to the rest of the economy through the so-called spillover effect (Sarbapriya R.2012), which is one of the most important effects of FDI. The modern theoretical economic debate insists that FDI encourages economic growth starting with improving the level of technology used in the economy, and this effect is more important than the importation of capital. There are at least three different modes of technology transfer internationally, such as high-tech products, learning through exports and FDI, (Hezron and Pauline, 2016).

While FDI is a means of transferring technology to host economies, but it is not unlikely that it will contribute to 
the creation of a dual economy by creating sophisticated but isolated activity in an underdeveloped economy. Economists, therefore, focus attention on the so-called spillover effect, which is called the situation in which FDI inflows into an economic sector contribute to the spread of technology to other sectors (Newman C. et el 2015). However, some cases indicate an inverse relationship between FDI inflows and productivity growth in local enterprises, which may be due to the introduction of new technologies, assumes that highly qualified workers have been trained, and able to use the technology. If the human capital stock is low, the chances of technology transfer to these countries will be lower, And In the case of markets that lack competitiveness,(Blomström \& Koko A.1997), the example of the entry of foreign companies coincides with the loss of local enterprises to their share in the domestic market, which will reduce their ability to use the volume indices and thus will have a direct negative impact on production,(Horas D.,2017). The negative effects of FDI can also occur as a result of returning profits to the original home of foreign companies and also through the so-called market stealing effect. As well as their positive effects on income distribution in the short run (Melnyk et el,2014).

\section{Literature Review}

In their attempt to estimate the relationship between FDI and economic growth, economists differentiate between the use of the Neo-Classical Model, which assumes that increased investment promotes economic growth and the Endogenous Growth Model, which assumes that growth is a function of technological progress, The weak performance of neo-classical theories in shedding light on the sources of long-run growth and the interpretation of large differences in economic performance among different countries, led to the emergence of the theory of internal growth, which contributed to the addition of factors of learning and gain knowledge from production to growth models (Todaro \& Stephen, 2015).

Barrel \& Nigel pointed out that the growth trajectory after the Second World War was determined by a number of factors such as trade openness, FDI and innovation, and discussed the factors driving FDI growth and its impact on the economy of the host countries. They found signs of reallocation of production on exports to a number of OECD countries. There were also traces of technology transfer in the form of the introduction of advanced equipment to host countries and became the most important channel for the reception and spread of new ideas and technology (Barrel \& Nigel, 1997).

Blomström \& Koko concluded that the potential spillover benefits are realized only if local firms have the ability and motivation to invest in absorbing foreign technologies and skills. To motivate subsidization of foreign investment, it is therefore necessary, at the same time, to support learning and investment in local firms as well (Blomström \& Koko,2003). (Balasubramanyam M. et el,1996) tried to test Bhagwati's hypothesis on a group of developing countries which indicate that there is a difference in the degree of the impact of FDI on economic growth between countries that adopt an export promotion (EP) and countries closed off import substitution (IS). The elasticity of output to FDI in the first group was found to be greater than the second.

Stanisic came from the premise that FDI has two simultaneous effects, namely, the impact on economic growth and the impact on export performance. The test did not reveal any positive relationship between FDI and economic growth. This is because the countries of the sample of the study are in transition of the structural changes and the production and use are decreasing in the inefficient establishments (Stanisic,2008). Lamine \& Yang utilized Granger's causality to test the relationship 
between FDI and economic growth in Guyana and found that the size of this investment was still below the level that would qualify for economic growth. But Granger's reasoned test is that FDI is capable of increasing gross domestic product, which in turn encourages FDI (Lamine \& Yang, 2010).

Sarbapriya use the cointegration test to test the gap between FDI and economic growth in India for the period of 1990-2011. The relationship between the two variables was found to be integrative at order one using Kwiatkowski, Phillips, Schmidt, and Shinn (KPSS) tests. Johansen's cointegration test confirmed a long-run equilibrium relationship between the two variables. Granger's test of a one-way causal relationship (from economic growth to FDI). The model of error correction is that the relationship between the two variables is statistically significant in the long run. The Indian government should work to improve infrastructure and develop human capital to increase growth rates (Sarbapriya R.2012).

In their presentation (Almfraji \& Almsafir, 2014) of the results of a number of empirical studies that were conducted to test the relationship between economic growth and FDI during the period 1994-2012, they found that most of them revealed a positive and moral relationship between the two variables, and in a few cases found an inverse relationship.

Naqeeb Ur Rehman Used two models to test the relationship between economic growth and FDI for a time series for the period of 1970-2012 in an effort to test different experimental approaches to estimate the relationship between the two variables. The error correction test is that FDI depends on economic growth and vice versa is not true. The second model is that FDI, human capital, and exports are important detrainments of economic growth (Naqeeb R., 2015).

Leandro used the ARDL as well as the ECM- Granger causality analysis, and found that a long-run relationship between FDI and economic growth had a positive and moral effect on the latter. There was also a causal relationship between the two variables (Leandro et al., 2017). Cointegration test has been applied by (Najaf \& Mingque,2018), it shows that there is a longterm interrelationship within FDI and economic growth and then applied the Granger causality (GC) test which is based on the VECM. The short run results show that there is no evidence of causality, testing the short period between the absence of causation in both directions between the two variables, Long-run test revealed the impact of FDI on economic growth but not significant. While the negative and moral impact of GDP on the FDI. Sultanuzzaman \& Wang concluded a significant causal relationship between FDI and GDP growth in Bangladesh by bringing advanced technology, investment capital, and knowledge that have become necessary for the growth of output (Sultanuzzaman \& Wang,2018).

Finally (Okoro et el, 2019) Experienced the impact of global capital flows on economic growth in Nigeria, the study adopted the Harrod-Domar model, the test of cointegration and the mode of conventional micro-data analysis. Among these inflows, FDI had a significant effect on economic growth, while other types of flows did not have a significant impact on Nigeria's economic growth.

It has been noted that empirical studies have followed most of the hypotheses about the expected relationship of FDI and economic growth. Although the hypothesis of positive and moral relationship is achieved, there are differences in the size and nature of the impact according to levels of development, nature of infrastructure, foreign trade policies, Human capital and government policies to attract FDI and the ability to transfer the impact of knowledge and technology to domestic 
economic activities that host these investments.

\section{Methodology}

\subsection{Data \& Model Description}

This study is an attempt to estimate the relationship between FDI and economic growth in three international country groups, which are classified according to the level of per capita income (low, middle and high income) and annual data for 1989-2018. The proposed model includes two basic variables: FDI and economic growth (EG). All the data used are taken from the World Bank database. To examine the relationships between the two variables, analysis is done through following steps:

- The stationarity test of the time series FDI \& EG, The Augmented Dickey-Fuller (ADF) and PhillipsPerron (PP) Unit Root Tests are employed to test the integration level and the possible cointegration among the variables.

- To investigate a long-run relationship between the variables under consideration, the Augmented Engle-Granger, Johansen and, bounds test for cointegration within the autoregressive distributed lags (ARDL) modeling approach was adopted.

- Other step of analysis has been carried out to explore the structural stability and diagnostic tests.

\subsection{Model Description}

The chosen model takes into consideration its ability to estimate all the parameters and thus test the hypotheses referred to above: The assumed model takes the following formula (Sarbapriya R.2012):

$\mathrm{GDP}=\mathrm{f}(\mathrm{FDI})$

When GDP, FDI, refers to GDP growth rate and FDI respectively. The relationship between the two variables can be modeled on the following linear model (Kisswani M.,25-40, Shalini T.\& Shaila S.,2018):

$\mathrm{GDP}=\alpha+\beta \mathrm{FDI}+\mu \mathrm{t}$

Where $\mu \mathrm{t}$ refers to the random variable or the error threshold, $\alpha$ and $\beta$ to the regression parameters.

\section{Empirical Results}

The long-run relationship between the two variables will be tested. The first step of analysis is to test whether the time series evidence is stable or not. Because such data are often unstable, they suffer from the root of the unit, causing a false regression. The problems arising from such regression were illustrated by (Granger and Newbold, 1974), with the aim of confirming the precondition of stability.

\subsection{Unit Root Test}

The Augmented Dickey- Fuller (ADF) and Phillips Perron (PP) tests were conducted to reinforce the graphical analysis findings. The results of the ADF and PP tests are presented in Table 5.1

Table 5.1

ADF and PP Test Results for all country groups

\begin{tabular}{|c|c|c|c|c|c|c|c|}
\hline 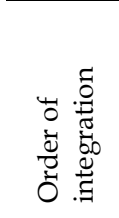 & $\begin{array}{l}\frac{0}{0} \\
\frac{\pi}{\pi} \\
\frac{\pi}{0} \\
>\end{array}$ & 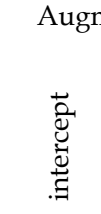 & 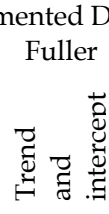 & Dickey- & 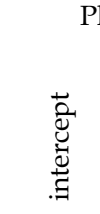 & 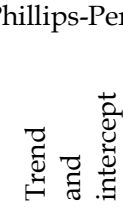 & $\begin{array}{l}\text { ॄี } \\
\text { Z }\end{array}$ \\
\hline Level & EGL & -2.05074 & -2.38330 & -0.59989 & -2.05659 & $9-2.57472$ & -0.7147 \\
\hline $\begin{array}{l}1^{\text {st }} \\
\text { difference }\end{array}$ & EGL & $-4.8181^{*}$ & $-4.8371^{*}$ & $-4.8301^{*}$ & $-5.8303^{*}$ & $-5.75285^{*}$ & $-5.886^{\star}$ \\
\hline Level & FDIL & -1.6957 & -2.10467 & $7-0.06402$ & -1.5251 & -2.2210 & -0.0982 \\
\hline $\begin{array}{l}1^{\text {st }} \\
\text { difference }\end{array}$ & $e^{\text {FDIL }}$ & $-4.4175^{*}$ & $-4.1833^{*}$ & $-4.1109^{*}$ & $-5.4758^{*}$ & $-5.4851^{*}$ & $-5.4305^{*}$ \\
\hline Level & EGM & -2.6072 & -2.9081 & -0.8088 & -2.5699 & -2.8355 & -0.5158 \\
\hline $\begin{array}{l}1^{\text {st }} \\
\text { difference }\end{array}$ & $e^{E G M}$ & -6.0960 & -6.1821 & -6.1529 & -8.2020 & -10.1573 & -8.1738 \\
\hline Level & FDIM & -2.0995 & -1.1428 & -0.0502 & -2.0997 & -1.0859 & $-0.1051^{*}$ \\
\hline $\begin{array}{l}1^{\text {st }} \\
\text { difference }\end{array}$ & $e^{\text {FDIM }}$ & $-4.9020^{*}$ & $-5.8189^{*}$ & $-4.9214^{*}$ & $-4.9217^{\star}$ & $-6.5959^{*}$ & $-4.9430^{*}$ \\
\hline Level & EGH & $-4.2457^{*}$ & $-4.3594^{*}$ & $-2.0433^{* *}$ & $-4.2467^{*}$ & $-4.3691^{*}$ & $-1.9288^{* * *}$ \\
\hline Level & FDIH & -2.1336 & -2.8205 & -0.9823 & -2.2894 & -2.3347 & -1.0579 \\
\hline $\begin{array}{l}1^{\text {st }} \\
\text { difference }\end{array}$ & $e^{\mathrm{FDIH}}$ & $-4.1400^{*}$ & $-4.1484^{*}$ & $-4.2306^{*}$ & $-4.1666^{*}$ & $-4.1675^{* \star}$ & $-4.2523^{* *}$ \\
\hline
\end{tabular}

Source: Eviews; Authors calculation

$*, * *, * * *$ represents stationary at $1.0 \%, 5 \% \& 10 \%$ levels of significance respectively

The unit root tests using intercept and trend suggests that all series are non-stationary in level, and becomes stationary after differencing fexcept the Economic growth variable in high income group countries (EGH). Thus, except (EGH) the variables become integrated of order one, I(1). both ADF and PP tests produced similar 
results. It shows that the series of (EG and FDI) are nonstationary at level with their test statistics are greater (negative value) than the critical values in all cases, But the series (EGH) is integrated at the level. Based on these results, different cointegration test are adopted for each country group.

\subsection{Cointegration Tests}

To verify that there is a cointegration between (FDI) and (EG), and, due to the results of the stationary tests, we will use both the Augmented Engle-Granger method and, the Johansen cointegration method, for both (LIG, MIG Countries), because all the related variables are integrated of the same order. However, for the case of (HIG) countries, auto regressive distributed lag models (ARDL), is adopted, because the both series aren't integrated of the same order.

\subsubsection{Cointegration Tests for LIG and MIG Countries}

$\mathrm{ADF}$ and PP tests shows that the series of (EGL, EGM, FDIL, and FDIM) are stationary at the first difference regardless whether the assumption of both intercept and intercept and trend are hold. Thus, it is obvious that the Cointegration test by Johansen and or Engel -Granger test will be adopted.

\subsubsection{Engle-Granger Method for Cointegration Analysis}

A number of methods for testing cointegration have been proposed in the literature. We consider here the simple method of ADF unit root test on the residuals estimated from the cointegrating regression. All we have to do is estimate a regression like $\left(E G_{t}=\beta_{1}+\beta_{2} F_{I}+U_{t}\right)$, obtain the residuals, and use the ADF tests. There is one precaution to exercise, however. Since the estimated ut are based on the estimated cointegrating parameter $\beta 2$, the ADF critical significance values are not quite appropriate. Engle and Granger have calculated these values, which can be found in the references, (Gujarati,2004,848-9). Therefore, ADF test in the present context is known as Augmented Engle-Granger (AEG) test.

This method involves passing two steps, first estimating the relationship involved in the normal least squares method and obtaining the residue from this estimate, and the second testing the stationary of the residue obtained from the first step. If the residue is still at the level, this indicates that there is a cointegration between the variables and that the relationship estimated in the first step is correct and not misleading. If the residues are not static at the level, there is no long-run equilibrium relationship between the variables and the previous relationship is misleading and cannot be invoked.

Applying the Engle-Granger method, we first regressed FDI on EG and obtained the following regressions:

$$
\begin{aligned}
& \text { i. } \quad E L_{t}=1.619349+0.823994 \text { FDIL }_{t} \quad \ldots \ldots \ldots \text { (4.1) } \\
& \mathrm{t}=(3.186664) \quad(2.139527) \\
& \mathrm{R} 2=0.266148, \mathrm{D} . \mathrm{W}=0.76079 \\
& \text { ii. } \quad \mathrm{EGM}_{\mathrm{t}}=0.76594+1.883485 \mathrm{FDIM}_{\mathrm{t}} \ldots \ldots \ldots \text { (4.2) } \\
& \mathrm{t}=(5.689489) \quad(0.094547) \\
& \mathrm{R} 2=0.536196, \mathrm{D} \cdot \mathrm{W}=0.1 .382123
\end{aligned}
$$

Obtaining the residuals ( $\mathrm{Ul}_{\mathrm{t}}$ for LIG, Umt for MIG) and conducting Augmented Dickey Fuller test to check the residual stationary, we have:

\section{Table 5.2}

ADF unit root test for residuals

\begin{tabular}{lllll}
\hline \hline \multirow{2}{*}{$\begin{array}{l}\text { Order of } \\
\text { integration }\end{array}$} & variables & & \multicolumn{3}{c}{ Augmented Dickey-Fuller } \\
\cline { 3 - 5 } & & -2.54525 & -2.547954 & -2.59241 \\
\cline { 3 - 5 } & $\mathrm{Ul}_{\mathrm{t}}$ & -3.890129 & -4.102968 & -3.95880 \\
\hline Level & $\mathrm{Um}_{\mathrm{t}}$ & -3 Nend and & \\
\hline \hline
\end{tabular}

Source: Eviews; Authors calculation

However, the $5.0 \%$ critical $\tau$ value is -3.29 . Since the computed $\tau(=t)$ value is less negative than this, which is not significant, our conclusion is that the residuals from the regression of FDIL on EGL are not $\mathrm{I}(0)$; is nonestationary. which means acceptance of the null 
Hypothesis, therefore there is no evidence of a cointegration relationship between FDIL and EGL.

Since the computed $\tau(=t)$ value is much more negative than this in the MIG Countries model, our conclusion is that the residuals from the regression of FDIM on EGM are $\mathrm{I}(0)$; i.e., they are stationary. Hence, (4.2) is a cointegrating regression and this regression is not spurious, even though individually the two variables are nonstationary. we can call (4.2) the static or long run growth function and interpret its parameters as long run parameters. Thus, 0.76594 represents the long-run equilibrium coefficient of the FDI on annual economic growth in the MIG countries.

\subsubsection{Johansen Cointegration Test for the Impact of FDI on Economic Growth}

Johansen (1991), argues that cointegration can be employed to show whether or not there exists a linear long-run relationship between variables of interest (Immurana M. et el,2015). One advantage of this test lies in its insensitivity to the choice of the endogenous variables. Decision with regards to long-run relationship is made by relying on the trace and maximum eigenvalue statistics. The application of the Johansen method of cointegration gave the results presented in Table 5.2 below.

Table 5.3

Unrestricted Cointegration Rank Test (Trace\& Eigenvalue)

\begin{tabular}{|c|c|c|c|c|c|}
\hline \multirow{9}{*}{$\begin{array}{l}\text { Low } \\
\text { Income } \\
\text { Group } \\
\text { of } \\
\text { Countries }\end{array}$} & \multicolumn{5}{|c|}{ Unrestricted Cointegration Rank Test (Trace) } \\
\hline & $\begin{array}{l}\text { Hypothesized } \\
\text { No. of CE(s) }\end{array}$ & Eigenvalue & $\begin{array}{l}\text { Trace } \\
\text { Statistic }\end{array}$ & $\begin{array}{l}0.05 \\
\text { Critical } \\
\text { Value }\end{array}$ & Prob.* \\
\hline & None & 0.334270 & 13.87948 & 15.49471 & 0.0863 \\
\hline & At most 1 & 0.084994 & 2.487103 & 3.841466 & 0.1148 \\
\hline & \multicolumn{5}{|c|}{ Unrestricted Cointegration Rank Test (Eigenvalue) } \\
\hline & $\begin{array}{l}\text { Hypothesized } \\
\text { No. of CE(s) }\end{array}$ & Eigenvalue & $\begin{array}{l}\text { Max } \\
\text { eigenvalue }\end{array}$ & $\begin{array}{l}0.05 \\
\text { Critical } \\
\text { Value }\end{array}$ & Prob.** \\
\hline & None & 0.334270 & 11.39238 & 14.26460 & 0.1356 \\
\hline & At most 1 & 0.084994 & 2.487103 & 3.841466 & 0.1148 \\
\hline & Unrestricted C & ointegration & Rank Test & Trace) & \\
\hline \multirow{2}{*}{$\begin{array}{l}\text { Middle } \\
\text { Income } \\
\text { Group }\end{array}$} & $\begin{array}{l}\text { Hypothesized } \\
\text { No. of CE(s) }\end{array}$ & Eigenvalue & $\begin{array}{l}\text { Trace } \\
\text { Statistic }\end{array}$ & $\begin{array}{l}0.05 \\
\text { Critical } \\
\text { Value }\end{array}$ & Prob.** \\
\hline & None* & 0.374786 & 18.48297 & 15.49471 & 0.0172 \\
\hline
\end{tabular}

$\begin{array}{llllll}\text { of } & \text { At most } 1^{*} & 0.173409 & 5.332466 & 3.841466 & 0.0209\end{array}$ Countries Unrestricted Cointegration Rank Test (Eigenvalue)

\begin{tabular}{lcllll}
$\begin{array}{l}\text { Hypothesized } \\
\text { No. of CE(s) }\end{array}$ & Eigenvalue & $\begin{array}{l}\text { Max } \\
\text { eigenvalue }\end{array}$ & $\begin{array}{l}0.05 \\
\text { Critical } \\
\text { Value }\end{array}$ & Prob. $^{* *}$ \\
None & 0.374786 & 13.15051 & 14.26460 & 0.0744 \\
At most $1^{*}$ & 0.173409 & 5.332466 & 3.841466 & 0.0209 \\
\hline
\end{tabular}

Source: Eviews; Authors calculation

Both test statistics showed results similar to that of augmented Engle-Granger.

Clearly, for the (LIG) countries, the values of (p) from the table show that there can be no rejection of the hypothesis that there is no cointegration vector and this supports our findings in the Engel-Granger method.

For the (MIG) countries, specifically, using the trace test statistic, the null hypothesis of no cointegration was rejected at $5 \%$ significance level since some test statistics were greater than their respective critical values Thus, confirming the existence of a stable long-run relationship among, FDIM, to EGM. But relying on the maximumeigenvalue test statistic, led to a counter conclusion.

\subsubsection{Autoregressive Distributed Lag Models (ARDL)}

The ARDL approach to test cointegration (developed by Pesaran and Shinn (1997) (Esso L.,2010) has been used here due to all the variables used in this analysis are not integrated of the same order. ARDL captures the data generating process in a general-to-specific framework by incorporating sufficient lags and incorporates the shortrun dynamics through ECM without losing the long-run information.

\subsubsection{The preliminary estimation of the ARDL model}

This estimation includes the annual rate of GDP growth (EGH) as a dependent variable and FDIH as an explanatory variable, shows that the model is significant as a whole through the $\mathrm{F}$ test, and, the value of the adjusted $\mathrm{R}^{2}$ coefficient $\left(\mathrm{R}^{-2}=45.7 \%\right)$ which gives the explanatory power for the model.

Table 5.4 preliminary tests of the ARDL model

\begin{tabular}{llll}
\hline \hline Estimators & Coefficients & Estimators & Coefficients \\
\hline
\end{tabular}




\begin{tabular}{|c|c|c|c|}
\hline R-squared & 0.537629 & $\begin{array}{l}\text { Mean } \\
\text { dependent var }\end{array}$ & 2.119374 \\
\hline $\begin{array}{l}\text { Adjusted } \\
\text { squared }\end{array}$ & R- 0.457217 & $\begin{array}{l}\text { S.D. dependent } \\
\text { var }\end{array}$ & 1.350708 \\
\hline $\begin{array}{l}\text { S.E. } \\
\text { regression }\end{array}$ & of 0.995119 & $\begin{array}{l}\text { Akaike info } \\
\text { criterion }\end{array}$ & 2.988523 \\
\hline $\begin{array}{l}\text { Sum square } \\
\text { resid }\end{array}$ & ed 22.77601 & $\begin{array}{l}\text { Schwarz } \\
\text { criterion }\end{array}$ & 3.226417 \\
\hline Log likelihood & -36.83932 & $\begin{array}{l}\text { Hannan-Quinn } \\
\text { criter. }\end{array}$ & 3.061250 \\
\hline F-statistic & 6.685899 & $\begin{array}{c}\text { Durbin- } \\
\text { Watson stat }\end{array}$ & 1.745443 \\
\hline Prob(F-statistic & c) 0.001009 & & \\
\hline
\end{tabular}

\subsubsection{Bound Test}

ARDL Bounds Testing Approach for Cointegration is a statistical property of time series variables. Two or more time series are cointegrated if they share a common stochastic drift. In other words, if there exists a stationary linear combination of non-stationary random variables, the variables combined are said to be cointegrated. ARDL long run form and bound test result are showed in the table (5.5) below:

Table 5.5

Bound Test Criteria

\begin{tabular}{lcc}
\multicolumn{3}{c}{ Bound Test Criteria } \\
\hline \hline Critical values & \multicolumn{3}{c}{ F. Statistic } \\
\cline { 2 - 3 } & \multicolumn{3}{c}{10.39051} \\
& $1(0)$ & $1(1)$ \\
\hline $10 \%$ & 3.02 & 3.51 \\
$5 \%$ & 3.62 & 4.16 \\
$2.5 \%$ & 4.18 & 4.79 \\
$1 \%$ & 4.94 & 5.58 \\
\hline \hline
\end{tabular}

Source: Eviews; Authors calculation

It is noticed in Table (5.5) that the statistical value $(\mathrm{F})$ is (10.39051), which is greater than the maximum critical values at the level of (1\%) which equals (5.58), which means acceptance of the alternative hypothesis that there is a long-run equilibrium between the dependent and explanatory variables for the duration period.

\subsubsection{Estimation of long-run and short-run relationship}

\section{a. Long-run relationship:}

In Table (5.6), there is a long-run response between (EGH) and (FDIH). Here the long- and short-run results are consistent with the assumption in the model that the
FDIH parameter is directly correlated with the annual rate of GDP growth (EGH).

From the Long-run estimates for the ARDL Model, we note the positive impact of investment on economic growth rates, where the increase of investment by $1 \%$ leads to increase economic growth rates by $0.584876 \%$, Note that the FDI parameter is statistically significant, at less than $5 \%$, That is, we reject the null hypothesis and say that the parameter is statistically significant at $5 \%$ level. The explanation for this relationship is that FDI inflows positively affect economic growth and contribute to increasing its rates.

Table 5.6

Long-run estimates for the ARDL Model

\begin{tabular}{rrcrc}
\hline \hline & & & & \\
\hline Variable & Coefficient & Std - Error & T- Statistic & Prob. \\
FDIH & -0.315962 & 0.157153 & -2.010537 & 0.0562 \\
$\mathrm{C}$ & 2.842400 & 0.412265 & 6.894600 & 0.0000 \\
\hline \hline
\end{tabular}

Source: Eviews; Authors calculation

\section{b. Short run relationship:}

The error correction model shows that the explanatory variable is statistically insignificant at the 5\% level, which means that the investment impact on the growth rate in the long- run is negative and significant only at the $10 \%$ level.

The results of the error correction model showed that the error correction slowdown coefficient reveals the speed (or slow) of the variables returning to the equilibrium state. Restoring the equilibrium state, the negative signal shows the short-run dynamic model convergence and the negative and moral coefficient associated with slowing the error correction limit, is more effective way of demonstrating cointegration. In this model, the value of the error correction coefficient CointEq (-1), which means the error correction speed, is negative and is about $-1.086045 \%$ and we note that it has a strong statistical significance at the level of $0.000 \%$, which increases the accuracy and validity of the equilibrium 
relationship in the long run, which means the error correction speed, is negative and is about $-1.086045 \%$ and we note that it has a strong statistical significance at the level of $0.000 \%$, which increases the accuracy and validity of the equilibrium relationship in the long run, It also indicates that the growth rate in one slow period reached (1.086045) with a negative signal and a probability of 0.000 , which means that the annual growth rate passes shocks in the short term by (1.086045) years, that is, the growth rate is due to its long-term equilibrium over a period of (2.08) years and passes Full shocks in the short term.As shown in Table (5.7) that the error correction coefficient takes a negative signal which is statistically significant at a level less than $1 \%$, which means that $(-1.086045)$ is the error correction run of the short-run un equilibrium or deviation in the explanatory variables in the previous year to the current year, In addition, the short-run parameters show that the explanatory variables were significant, i.e. there is a short-run relationship between the dependent variable, i.e., annual growth rate of GDP (EGH), and the explanatory variable, i.e., FDI (FDIH), which it is parameter is statistically significant.

Table 5.7

short-run estimates for the ARDL Model

\begin{tabular}{lllll}
\hline \hline \multicolumn{2}{l}{ Long Run Coefficients } & & & \\
\hline Variable & Coefficient & Std - Error & T- Statistic & Prob. \\
FDIH & 0.584876 & 0.213186 & 2.743504 & 0.0116 \\
CointEq (-1) & -1.086045 & 0.195497 & -5.555308 & 0.0000 \\
\hline \hline
\end{tabular}

Source: Eviews; Authors calculation

\subsubsection{Structural stability tests}

The structural stability test of the estimated long-run and short-run relationship requires a cumulative sum control chart (CUSUM) to test for the absence of any structural changes in the data used. Critical level (5\%), which confirms that the variables of the study are stable and Figure (1) translates the static long and short-run parameters of the model, which indicates stability between the variables studied phenomenon because they are all within the limits of confidence during the study period. The graph shows that the total cumulative sum control chart CUSUM remaining for this pattern is an average line within the boundaries of the critical region, indicating the stability of the pattern at a large $5 \%$ boundary. The cumulative sum of the squares of the residuals (CUSUM of Squares) Figure (2) represents an average line within the boundaries of the critical area, with the exception of a small deviation outside the frame in the 2008 economic crisis.

The similar result for (MIG) countries is shown in the Figures $(3,4)$, the both (CUSUM, CUSUM of squares) represents an average line within the boundaries of the critical area. Vice versa, considering the (LIG) countries, we found in Figures $(5,6)$, the (CUSUM), represents an average line outside the boundaries of the critical area during the period (1989-2018). While the (CUSUM of squares) represents an average line within the boundaries of the critical area.

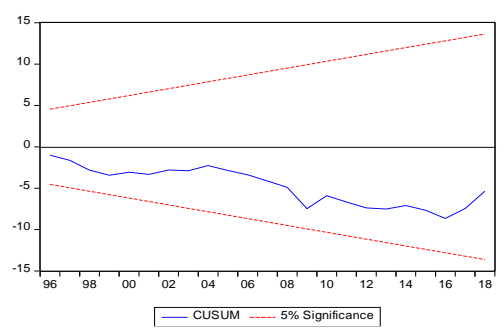

Fig. 1

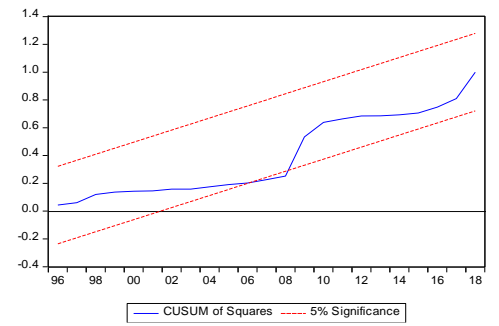

Fig. 2 


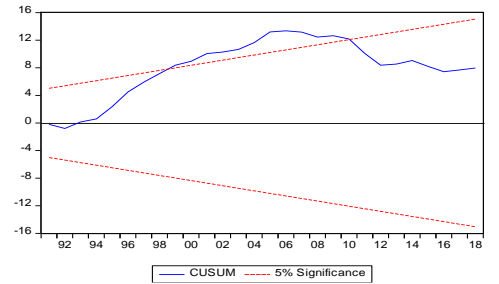

Fig. 3

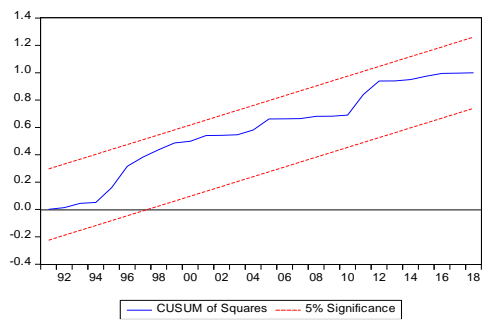

Fig. 4

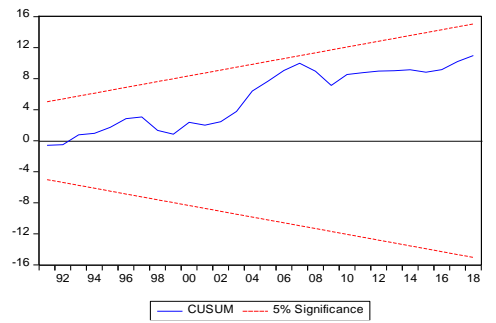

Fig. 5

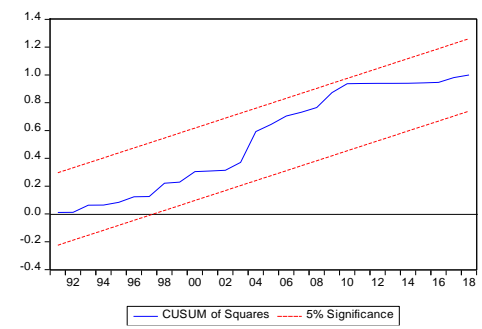

Fig. 6

Source: Eviews; Authors calculation

\subsubsection{Diagnostics tests:}

Here we will test for both serial correlation between the errors and, the Heteroscedasticity tests.

In order to test the hypothesis of non-correlation of errors, we use a serial-correlation test (Breusch-Godfrey Serial Correlation). Hence Lagrange multiplier LM $<\chi^{2}$ and probability values are not significant at $5 \%$, this means that there is no subjective correlation for the remainder of the estimated model as shown in the table below:

Table 5.8

Breusch-Godfrey Serial Correlation outputs Breusch-Godfrey Serial Correlation

\begin{tabular}{|c|c|c|c|c|}
\hline LIG & F-statistic & & Prob. & \\
\hline Countries & & 9.714130 & $F(2,26)$ & 0.0007 \\
\hline \multirow{4}{*}{$\begin{array}{l}\text { MIG } \\
\text { Countries }\end{array}$} & $\begin{array}{l}\text { Obs*R- } \\
\text { squared }\end{array}$ & 12.83007 & $\begin{array}{l}\text { Prob. Chi- } \\
\text { Square (2) }\end{array}$ & 0.0016 \\
\hline & F-statistic & & Prob. & \\
\hline & & 1.938998 & $F(2,26)$ & 0.1641 \\
\hline & $\begin{array}{l}\text { Obs*R- } \\
\text { squared }\end{array}$ & 3.893832 & $\begin{array}{l}\text { Prob. Chi- } \\
\text { Square (2) }\end{array}$ & 0.1427 \\
\hline \multirow[t]{3}{*}{$\begin{array}{l}\text { HIG } \\
\text { Countries }\end{array}$} & F-statistic & 0.179354 & $\begin{array}{ll}\text { Prob. } & \text { F } \\
(1,32) & \end{array}$ & 0.8371 \\
\hline & $\begin{array}{l}\text { Obs*R- } \\
\text { squared }\end{array}$ & 0.470245 & $\begin{array}{l}\text { Prob. Chi- } \\
\text { Square (1) }\end{array}$ & 0.7905 \\
\hline & $\begin{array}{l}\text { Obs*R- } \\
\text { squared }\end{array}$ & 0.003434 & $\begin{array}{l}\text { Prob. Chi- } \\
\text { Square (1) }\end{array}$ & 0.9533 \\
\hline
\end{tabular}

Source: Eviews; Authors calculation

There are several tests to detect that the residuals are homogeneous or not, among them the $\mathrm{ARCH}$ test. It was found that the model does not suffer from the problem of Heteroscedasticity, while the value of $\mathrm{LM}<\chi^{2}$ and the probability values are not significant at $5 \%$, and this indicates the Homoscedasticity of the residuals estimated, as shown in the table below:

Table 5.9

Heteroscedasticity Test: ARCH

\begin{tabular}{|c|c|c|c|c|}
\hline \multicolumn{5}{|c|}{ Heteroscedasticity Test: ARCH } \\
\hline LIG & F-statistic & & Prob. & \\
\hline Countries & & 2.699343 & $\mathrm{~F}(1,27)$ & 0.1120 \\
\hline & $\begin{array}{l}\text { Obs*R- } \\
\text { squared }\end{array}$ & 2.635781 & $\begin{array}{l}\text { Prob. Chi- } \\
\text { Square (1) }\end{array}$ & 0.1045 \\
\hline MIG & F-statistic & & Prob. & \\
\hline Countries & $\begin{array}{l}\text { Obs*R- } \\
\text { squared }\end{array}$ & 0.484788 & $\begin{array}{l}\mathrm{F}(1,27) \\
\text { Prob. Chi- } \\
\text { Square (1) }\end{array}$ & 0.4922 \\
\hline $\begin{array}{l}\text { HIG } \\
\text { Countries }\end{array}$ & F-statistic & 0.003180 & $\begin{array}{l}\text { Prob. } \\
(1,32)\end{array}$ & 0.9555 \\
\hline
\end{tabular}

Source: Eviews; Authors calculation

\section{Conclusions}

This study is an attempt to conduct an empirical evaluation of the relationship between FDI and economic growth in international country groups classified according to per capita income levels, i.e. (low, middle and high income) countries, using annual data from 1989 to 2018. Time series stability was tested using unit root tests of the Augmented Dickey-Fuller (ADF), the Phillips-Perron (PP) test, and then the cointegration, diagnostic and stability tests were performed. Key findings include: 
The unit root test showed that both economic growth and FDI are not stable at the level except the EGH series.

In contrast, all FDI and economic growth time series are stable at the first difference and for all international country groups.

for (LIG) countries, the results, as confirmed by the cointegration tests of Engle-Granger and shows that economic growth and FDI are not cointegrated, indicating that there is no long-run equilibrium relationship between the two variables, but, the vice versa for MIG countries, The Johansson's test show a long-run equilibrium relationship between the two variables. However, ARDL results confirmed that economic growth and FDI are cointegrated in highincome countries (HIG).

Structural stability tests showed results comparable to previous tests of all international groups concerned. As well as diagnostic tests found rejection of the null hypothesis and accept the alternative hypothesis, i.e., the absence of time series of serial link and the heterogeneity of variance. So, the we accept the Null hypotheses for(LIG) countries but, we rejected for (MIG \&HIG) countries. A key implication of this study is that policymakers should develop policies that will create an enabling environment for attracting FDI.

\section{References}

1. Almfraji b. \& Almsafir M., "Foreign Direct Investment and Economic Growth" Literature Review from 1994 to 2012, International Conference on Innovation, Management and Technology Research, Malaysia, 22 - 23 September, 2013, Procedia - Social and Behavioral Sciences 129 (2014) 206 213.

2. Barrel R. and Nigel P., "Foreign Direct Investment, Technological Change, and Economic Growth within Europe", the Economic Journal, Vol. 107, No. 445 (Nov., 1997), pp. 1770-1786.

3. Barro R. J., "Economic Growth in a Cross Section of Countries", The Quarterly Journal of Economics, Vol. 106, No. 2. (May, 1991), pp. 407-443.

4. Balasubramanyam V. N., et el, “Foreign Direct Investment and Growth in EP and is Countries" The Economic
Journal, Vol. 106, No. 434 (Jan., 1996), pp. 92-105.

5. Bezić "Technology transfer, FDI and economic growth in the EU transition countries and the republic of Croatia" Ekon. MISAO Praksa DBK. GOD XXIII. (2014.) BR. 2. (463482).

6. Blomström M. \&Koko A., "The Impact of Foreign Investment on Host Countries: A Review of the Empirical Evidence", Copy of World Bank Policy Research Working Paper No. 1745, Stockholm School of Economics, March 1997,

7. Blomström, M., \& Koko A. "The Economics of Foreign Direct Investment Incentives" NBER Working Paper No. 9489, February 2003, JEL No. J23, O12.

8. Blomström, M., \& Sjöholm, F. (1999). “Technology transfer and spillovers: does local participation with multinationals matter?" European Economic Review,43(4),915-923.

9. Ciccone A. \& Jarocinski M., "Determinants of Economic Growth: Will Data Tell?" European Central Bank, working paper, No 852, January, 2008.,antonio.ciccone@upf.edu.

10. Esso L., Long-Run Relationship and Causality between Foreign Direct Investment and Growth: Evidence from Ten African Countries" International Journal of Economics and Finance, Vol. 2, No. 2; May 2010, PP 168177.

11. Ghazali A.," Analyzing the Relationship between Foreign Direct Investment Domestic Investment and Economic Growth for Pakistan" International Research Journal of Finance and Economics, Issue 47 (2010),PP 123-131.

12. Granger and Newbold "Spurious regressions in Econometrics" Journal of Econometrics 2 (1974) 111-120.

13. 13.Grier \& Tullock" An empirical analysis of crossnational" Journal of Monetary Economics 24 (1989) 259276.

14. Gujarati D.," Basic econometrics" 4th ed., McGraw-Hill Higher Education, USA,2003.

15. 15.Hezron M.et el, "Role of foreign direct investment on technology transfer and economic growth in Kenya: a case of the energy sector" Journal of Innovation and Entrepreneurship (2016).pp 2-25.

16. Horas D., "Foreign Direct Investment and Technology Transfer: Knowledge Spillover in the Manufacturing Sector in Indonesia" Global Business Review, 18(1) 5770,2017.PP 57-70.

17. Immurana M. et el," FDI, Economic Growth and Service Sector Value Additions in Ghana" International Journal of Academic Research in Business and Social, Dec 2015, Vol. 5, No. 12

18. Kisswani K.M. et el, “The impact of FDI inflows on real GDP in Estonia: Evidence from a cointegration approach and causality test" The Journal of Developing Areas, Volume 49, Number 4, Fall 2015, pp. 25-40.

19. Kormendi, C. and Meguire P. G." Macroeconomic 
determinants of growth: Cross -country evidence" Journal of Monetary Economics. 1985,16:141-163.

20. Lamine M.\& Yang D., “Foreign Direct Investment Effect on Economic Growth:

21. Evidence from Guinea Republic in West Africa" International Journal of Financial Research, Vol. 1, No. 1; December 2010.

22. Lasbrey A." Foreign Direct Investment and Economic Growth: Literature from 1980 to 2018 "

23. International Journal of Economics and Financial Issues, 2018, 8(5), 309-318.

24. Leandro et el, "The relationship between FDI \& Economic growth \& Financial Development in Capo Verde" International Journal of Economics and Finance; Vol. 9, No. 5; 2017.

25. Melnyk L., et el, “The impact of foreign direct investment on economic growth: case of post communism transition economies" Problems and Perspectives in Management, Volume 12, Issue 1, 2014,pp17-24.

26. Najaf A. \&Ye M., "Does FDI lead to economic growth? Evidences from Asian Developing Countries" International Journal of Economics and Finance; Vol. 10, No. 3; 2018.

27. Newman C., "Technology transfers, foreign investment and productivity spillovers" European Economic Review76(2015)168-187.

28. OECD, "Foreign Direct Investment for Development" France, 2002.

29. Okoro, C. O., et el, "Effect of International Capital Inflows on Economic Growth of Nigeria" International Journal of Science and Management Studies (IJSMS), Volume: 02 Issue: 01, January to February 2019.pp 13-25.

30. Sarbapriya R., "Impact of Foreign Direct Investment on Economic Growth in India: A Co integration Analysis: Advances in Information Technology and Management (AITM), Vol. 2, No. 1, 2012, pp 187-200.

31. Shalini T.\& Shaila S.,"Integration of GDP and FDI in Economies at Different Stages of Growth" Theoretical Economics Letters, 2018, PP 2199-2219.

32. Solow R. M., "A Contribution to the Theory of Economic Growth" the Quarterly Journal of Economics, Vol. 70, No. 1 (Feb., 1956), pp. 65-94

33. Stanisic N.,"Do Foreign Direct Investments increase the economic growth of southern eastern European economies?" South-Eastern Europe Journal of Economics 1 (2008) 29-38.

34. Sultanuzzaman M.R. \& Wang B.,"The impact of foreign direct investment inflows on economic growth: Evidence from Bangladesh" Journal of Business and Retail Management Research (JBRMR), Vol. 12 Issue 2 · January 2018, PP211-223.
35. Todaro M. \& Stephen C. S., "Economic development"12Ed.,2015 Library of Congress Catalogingin-Publication Data, USA,2015. 